\title{
Effect of Potassium Silicate and NPK Fertilization Levels on Cotton Growth and Productivity under Different Sowing Dates
}

\author{
M.A.A. Emara ${ }^{(1) \#}$, S.A.F. Hamoda ${ }^{(1)}$ and Maha M.A. Hamada ${ }^{(2)}$ \\ ${ }^{(1)}$ Cotton Research Institute, Agricultural Research Center (ARC), Giza, Egypt; \\ (2) Agronomy Department, Faculty of Agriculture, Ain Shams University, Cairo, \\ Egypt.
}

\begin{abstract}
FIELD experiment was carried out in El-Gemmeiza Agric. Res. St., ARC, El-Gharbiya Governorate, during 2016 and 2017 seasons to study the effect of potassium silicate mineral or organic and different NPK fertilizer levels on growth and productivity of Egyptian cotton variety Giza 86 under different sowing dates. The experiment design was a split plot with four replications. The main plots had two sowing dates; (Early at $8^{\text {th }}$ April and Late at $8^{\text {th }}$ May) and the sub plots had nine treatments (1-100\% NPK Control, 2- 100\% NPK + potassium silicate mineral, 3- 100\% NPK + potassium silicate organic, 4- $125 \%$ NPK, 5- $125 \%$ NPK + potassium silicate mineral, $6-125 \% \mathrm{NPK}+$ potassium silicate organic, $7-75 \% \mathrm{NPK}, 8-75 \%$ $\mathrm{NPK}+$ potassium silicate mineral and $9-75 \% \mathrm{NPK}+$ potassium silicate organic).
\end{abstract}

The most important results obtained could be summarized as follows:

1) Sowing date had a significant effect on growth, earliness, seed cotton yield and its components, where, the early sowing date surpassed the late sowing date.

2) The levels of NPK $125 \%$ + foliar with potassium silicate organic sprayed three times at squaring, initiation of flowering and two weeks after flowering had significant effect on growth, seed cotton yield/fad and its components.

3) The interaction between sowing dates, NPK fertilizer levels with potassium silicate treatments had only significant effect on plant high and no. of sympodia/plant.

4) All treatments (sowing dates, levels of NPK $125 \%$ + foliar with potassium silicate and the interaction) wave exhibited any significant effect on all fiber properties.

Generally, from the results obtained revealed that early sowing date in combination with the NPK fertilizer $(125 \%)$ and foliar with potassium silicate organic sprayed three times at squaring, initiation of flowering and two weeks after flowering for obtaining gave the high productivity of Egyptian cotton variety Giza 86 in clay loam soil.

Keywords: Cotton, Sowing dates, Fertilizer, Potassium silicate, Growth, Yield and Quality.

\section{Introduction}

In Egypt, early sowing appears higher yield potential and alternately, late planting of cotton shows very vegetative growth and difficult to manage resulting in lower yield as well (Ali et al., 2009). Early sowing produced $23 \%$ more open bolls and 18\% more cotton yield (Arshad et al., 2007). However, several reports have indicated that early sown cotton produces taller plants with higher no. of branches, No. of bolls and yield (Bange et al., 2008). Emara et al. (2015 b) found that early planting date significantly increased seed cotton yield/fad due to the increase of No. of open bolls/plant, boll weight, seed cotton yield/ plant and No. of plants/fad at harvest. However, Deshish et al. (2015) indicated that all fiber properties studied were improved due to early planting of cotton. Emara (2012) indicated that sowing date gave significant effects on upper half mean length and micronaire reading in favour of early planting. While, did not exhibit any significant on uniformity index and strength.

NPK forms are the most important plant nutrients limiting plant growth and consequently

"Corresponding author email: mostafacotton@yahoo.com 
yield. In this respect, Policepatil et al. (2009) revealed that increased NPK fertilization to cotton may result in more accumulation of photosynthetic assimilates that resulted in higher fruit weight. Also, several studies were done to evaluate the response of cotton to different NPK levels, Seadh et al. (2012), Hamoda et al. (2014) and Emara et al. (2015 a) found that the final plant height, No. of fruiting branches/plant, No. of bolls/plant, boll weight, seed index, lint percentage and seed cotton yield/fad increased with increasing rates of NPK applied. Elhamamsey et al. (2016) and Emara et al. (2016) revealed that the high NPK fertilizer level did not exhibit significant effect on seed index, lint percentage and fiber properties. Emara \& Abdel-Aal (2017) found that the plant height, no. of fruiting branches/plant, No. of bolls/ plant, boll weight, seed index, seed cotton yield/ plant and /fad increased with increasing rates of NPK applied.

Potassium $(\mathrm{K})$ is an important nutrient that has favorable effects on the metabolism of nucleic acids, proteins, vitamins and growth substances. Furthermore, $\mathrm{K}$ plays an important role in the translocation of photsynthates from sources to sinks (Morteza et al., 2005). Many studies have shown increased yield and cotton productivity in response to potassium fertilization as reported by Abdel-Aal et al. (2014), Gomaa et al. (2014) and Emara (2014). Many studies have shown increased yield and cotton productivity in response to potassium fertilization as reported by Basbag (2008), Temz et al. (2009) and Abou-Zaid et al. (2013) stated that added potassium humate fertilizer as soil or foliar application improved growth, yield and its components of cotton plant.

The main objective of this investigation was to study the effect of potassium and different NPK fertilizer levels on growth and productivity of Egyptian cotton variety (Giza 86) under different sowing dates in El-Gemmeiza condations.

\section{Materials and Methods}

A field experiments was carried out at El-
Gemmeiza Agric. Res. St., ARC, El-Gharbiya Governorate, during 2016 and 2017 seasons to study the effect of potassium silicate mineral or organic and different NPK fertilizer levels on growth and productivity of Egyptian cotton variety Giza 86 under different sowing dates. The experiment design was a split-plot with four replications. The main plots were assigned to the two sowing dates (Early at $8^{\text {th }}$ April and Late at $8^{\text {th }}$ May) and the sub plots were allocated to nine treatments (1- 100\% NPK Control, 2- 100\% NPK + potassium silicate mineral, 3- $100 \%$ NPK + potassium silicate organic, 4- 125\% NPK, 5- 125\% $\mathrm{NPK}+$ potassium silicate mineral, $6-125 \% \mathrm{NPK}$ + potassium silicate organic, 7- 75\% NPK, 8- 75\% $\mathrm{NPK}+$ potassium silicate mineral and 9- 75\% NPK + potassium silicate organic). Potassium silicate mineral or organic sprayed three times (at squaring, floret initiation and two weeks after flowering). The sub-plot size was $19.5 \mathrm{~m}^{2}$ including six rows ( $5 \mathrm{~m}$ long and $0.65 \mathrm{~cm}$ width). The distance between hills was $25 \mathrm{~cm}$. Soil samples was taken in the two seasons before planting cotton to estimate the soil characters using the standard methods as described by Chapman \& Parker (1981). The results are shown in Table 1.

In both seasons, the soil texture was clay loam, low content of organic matter, low calcium carbonate and non-saline. The soils of the two seasons were low in total N, Extractable-P and low to medium in available $\mathrm{K}$ and $\mathrm{B}$.

Phosphorus in the form of superphosphate $\left(15.5 \% \mathrm{P}_{2} 0_{5}\right)$, the tested rates incorporated during seed bed preparation. Nitrogen fertilizer in the form of ammonium nitrate $(33.5 \% \mathrm{~N})$ at the tested levels was applied in two equal dose, the $1^{\text {st }}$ dose was applied after thinning and the $2^{\text {nd }}$ dose was added at the following irrigation. Potassium in the form of potassium sulphate $\left(48 \% \mathrm{~K}_{2} \mathrm{O}\right)$ at the tested rates was side-dressed in a single dose before the second irrigation. The other standard agricultural practices were followed throughout the two growing seasons. The other cultural practices were carried out as recommended for the conventional cotton planting.

TABLE 1. Mechanical and chemical analysis of the experiment soil in 2016 and 2017 seasons.

\begin{tabular}{lccccccccc}
\hline Season & \multirow{2}{*}{ Texture } & \multirow{2}{*}{ pH } & Organic & EC & \multicolumn{3}{c}{ Bicarbonate } & \multicolumn{3}{c}{ Available elements (ppm) } \\
& & & matter $(\mathbf{\%})$ & (m mhos/cm) & $\mathbf{( \% )}$ & $\mathbf{N}$ & $\mathbf{P}$ & $\mathbf{K}$ & $\mathbf{B}$ \\
\hline 2016 & Clay loam & 8.0 & 1.42 & 0.54 & 1.81 & 28.7 & 11.1 & 306 & 0.34 \\
2017 & Clay loam & 8.2 & 1.56 & 0.67 & 1.62 & 29.2 & 14.7 & 250 & 0.27 \\
\hline
\end{tabular}


In both seasons, ten representative plants were from the $2^{\text {nd }}$ ridge within each plot to determine the following traits: Plant height at harvest $(\mathrm{cm})$ and No. of sympodia/plant, No. of open bolls/ plant, boll weight $(\mathrm{g})$, lint $\%$ and seed index $(\mathrm{g})$. The yield of seed cotton in kentars/fad was estimated from the three inner ridges of each plot. Fiber quality; fiber length and uniformity index, fiber fineness and fiber strength were determined on digital Fibrograph instrument 630, Micronaire instrument 675 and Pressley instrument, respectively, according to A.S.T.M. (2012) at the Cotton Research Institute laboratories. Statistical analysis was done according to the procedures outlined by Snedecor \& Cochran (1980) using M Stat-C microcomputer program for a split-plot. The treatments means were compared by LSD and $\mathrm{F}$ test at $5 \%$ level of probability.

\section{Results and Discussion}

\section{Growth traits}

The results of growth traits as affected by sowing dates, levels of NPK $+\mathrm{K}$-silicate and its interaction of cotton during 2016 and 2017 seasons were shown in Table 2.

\section{Effect of sowing dates}

Data in Table 2 showed that sowing date had a significant effect on plant height at harvest and No. of sympodia/plant in 2016 and 2017 seasons. Late sowing date had significantly increased plant height compared with early sowing. However, early sowing date had significantly increased No. of sympodia/plant compared with to late sowing.

This effect may be due to the balance between vegetative and fruiting growth, which occurred under the earlier date, than late one. Similar results were obtained by Emara (2012), Emara et al. (2015 b) and Emara et al. (2016).

Effect of NPK levels and $K$-silicate

Results presented in Table 2 indicate that levels of NPK + K-silicate had significant effect on growth traits (plant height and No. of sympodia/plant) in both seasons. The high level of NPK $(125 \%)+$ K-silicate organic significantly increased plant height in general (174.63 and $176.68 \mathrm{~cm}$ ) and No. of sympodia/plant (14.50 and 15.95 ) in 2016 and 2017 seasons, respectively, as compared with the other treatments.

The positive response due to the high NPK rate $+\mathrm{K}$-silicate organic on growth is mainly related to the followings; $\mathrm{N}$ plays an important role in synthesis, distributing and accumulating the important substances responsible for growth and reflected greatly on plant dry weight (Hearn, 1981). In photosynthesis and respiration, P plays a major role in energy storage. Phosphorus works on organizing $\mathrm{pH}$ in plant cells because a large portion of it found as ions which works on keeping the hydrogen ion concentration at a level which makes the cell more active (Uchida, 2000). These results are in harmony with those obtained by Hamoda et al. (2014), Emara et al. (2015 a), Elhamamsey et al. (2016), Emara et al. (2016) and Emara \& Abdel-Aal (2017), found that plant height and No. of fruiting branches were significantly increased by increasing NPK rate.

Effect of interaction between sowing dates and NPK fertilizer levels with potassium silicate

Results presented in Table 2 indicate that interaction between sowing dates and levels of $\mathrm{NPK}+\mathrm{K}$-silicate treatments had significant effect on plant height and No. of sympodia/plant in 2016 and 2017 seasons. Late sowing date and high level of NPK $(125 \%)+$ K-silicate organic gave tallest plant height $(175.00$ and $178.05 \mathrm{~cm})$ and No. of sympodia/plant (14.60 and 16.02) in 2016 and 2017 seasons respectively, while in early sowing date with high level of NPK $(125 \%)+$ K-silicate organic gave (174.25 and $175.30 \mathrm{~cm})$ in plant height and (14.40 and 15.68) as No. of sympodia/plant in 2016 and 2017 seasons respectively, as compared with the other treatments.

\section{Yield and yield components}

The results of yield and its components as affected by sowing dates, levels of NPK + $\mathrm{K}$-silicate and its interaction of cotton during 2016 and 2017 seasons wire shown in Table 3.

\section{Effect of sowing dates}

Data in Table 3 cleared that No. of open bolls/ plant, boll weight and seed cotton yield/fad wire significantly increased due to the early sowing date in both studied seasons. Seed index and lint percentage were insignificantly affected by treatments. The sowing date produced high No. of open bolls/plant (17.34 and 14.55 bolls) and boll weight $(2.73$ and $2.66 \mathrm{~g})$ than late sowing date (16.27 and 12.98 bolls) and (2.66 and 2.60g) in 2016 and 2017 seasons, respectively. 


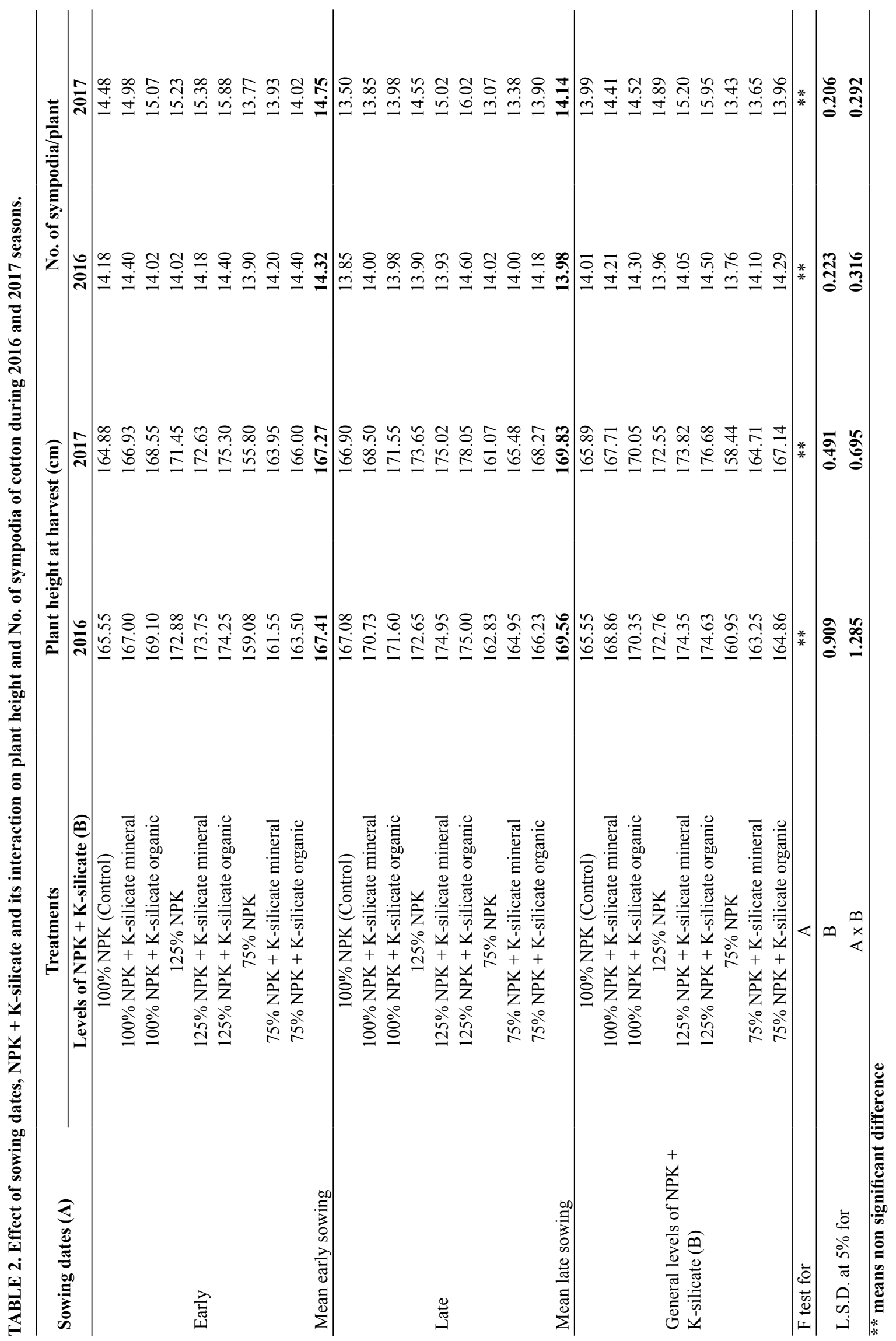

Egypt. J. Agron. Special Issue (2018) 


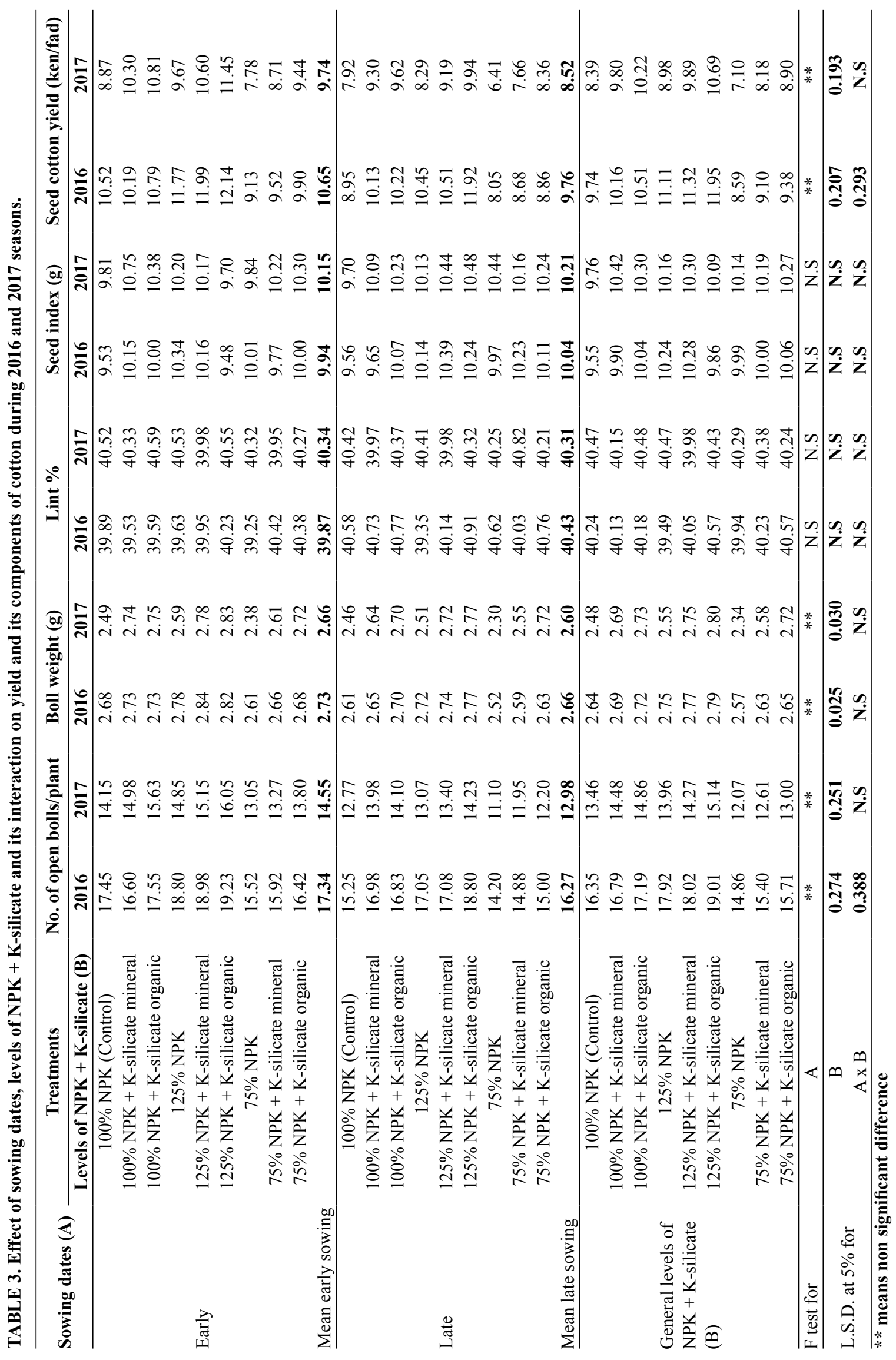


This could be attributed to the increase in the No. of sympodia/plant and the well-built plants, which were shorter and had lower fruiting node than the late sown plants, which were etiolated. This in turn might have had increased the amounts of available photosynthates for boll development and hence increased No. of open bolls/plant and boll weight.

The earlier sowing date surpassed the late sowing date in the increase of seed cotton yield/fad, owing to early sowing date were $9.12 \%$ and $14.32 \%$ for first and second seasons, respectively. The seed cotton yield/ fad was increased in favor of early sowing as a result of increasing No of open bolls/plant and boll weight. These results are in harmony with those obtained by Emara (2012), Emara et al. (2015 b), Deshish et al. (2015) and Emara et al. (2016).

\section{Effect of NPK levels $+K$-silicate}

The results in Table 3 show that, levels of $\mathrm{NPK}+\mathrm{K}$-silicate treatments had a significant effect on No. of open bolls/plant, boll weight and seed cotton yield/faddan, but insignificant effect on seed index and lint percentage in both seasons. The highest values of No. of bolls/plant, boll weight and seed cotton yield/ faddan were produced from the high level of NPK $125 \%+$ K-silicate organic, while the lowest values of No. of bolls/plant, boll weight and seed cotton yield/faddan were obtained from the level of NPK 75\% in 2016 and 2017 seasons, respectively.

The positive response to the high NPK level with regard to seed cotton yield and its components might be due to the improvement in nutrient availability and the increase in nutrients uptake. The role of these two concentrations to increase leaf $\mathrm{N}$, $\mathrm{P}$ and $\mathrm{K}$ content and consequently increase photosynthesis, assimilates accumulation and plant dry weight and the higher No. of open bolls/plant and heavier bolls. The boll weight increases due to the high NPK level mainly attributed to increase photosynthetic activity of cotton plants and consequently increase accumulation of metabolites with direct impact on boll weight. These results are in accordance with those outlined by Hamoda et al. (2014), Emara et al. (2015 a), Elhamamsey et al. (2016) and Emara \& Abdel-Aal (2017).
Effect of interaction between sowing dates and NPK fertilizer levels with potassium silicate

Results presented in Table 3 indicate that interaction between sowing dates and levels of $\mathrm{NPK}+\mathrm{K}$-silicate treatments had significant effect on No. of bolls/plant and seed cotton yield/faddan in first season only and had insignificant effect on boll weight, seed index and lint percentage in 2016 and 2017 seasons. Early sowing date and high level of NPK $(125 \%)+\mathrm{K}$-silicate organic gave high No. of bolls/plant (19.23) and seed cotton yield/ faddan $(12.14 \mathrm{ken} /$ fad in 2016 season only), as compared with the other treatments.

\section{Fiber quality traits}

Data in Table 4 shown effect of sowing dates, levels of NPK + K-silicate and its interaction of cotton during 2016 and 2017 seasons on fiber parameters (upper half mean length, length uniformity index, fiber strength and micronaire reading). The results in Table 4 indicate that, sowing dates, levels of NPK $+\mathrm{K}$-silicate and its interaction did not exhibit any significant effect on fiber properties under study in both seasons. This may be attributed to the realization that these characteristics were less affected by the environmental factors. These results are in accordance with those outlined by Hamoda et al. (2014), Elhamamsey et al. (2016) and Emara \& Abdel-Aal (2017).

\section{Conclusion}

The results obtained in this study could lead us to recommendations package, which seemed to be useful for increasing the cotton yield production and the best fiber quality. It could be concluded the early planting in combination with the high $\mathrm{N}$ fertilizer level $(60 \mathrm{~kg} \mathrm{~N} / \mathrm{fad})$ and foliar application with potassium silicate organic three times at squaring, floret initiation and two weeks after flowering obtaining the high productivity of Egyptian cotton (Giza 86) under this study clay loam soil. In addition, NPK are very important content nutrient; nitrogen for growth, phosphorus for floret incretion and potassium for distribute water and absorbed nutrients through xylem and also, distribute the photosynthetic substance through phloem to each part of the plant and using K-organic silicate more useful. 


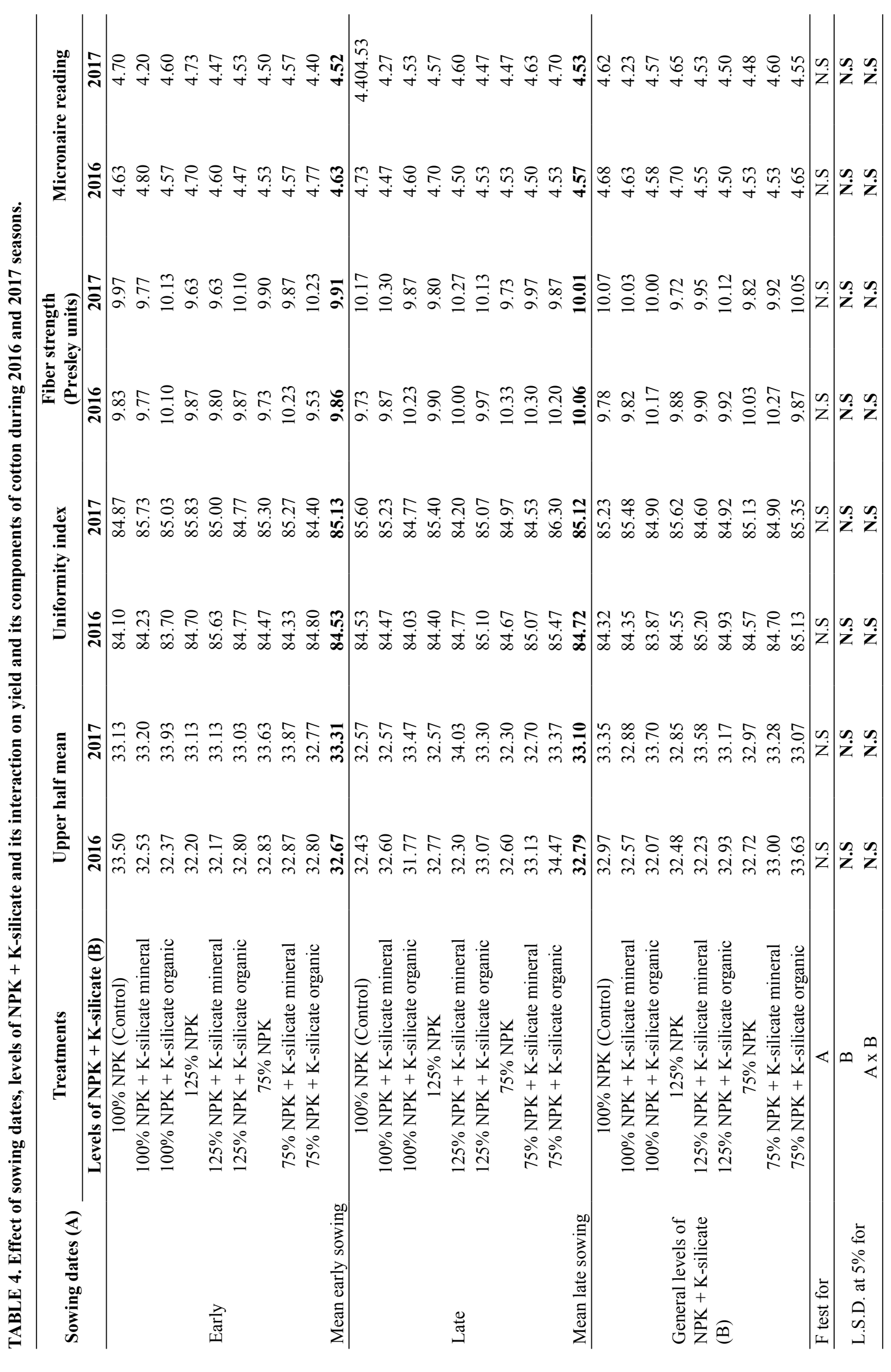

Egypt. J. Agron. Special Issue (2018) 


\section{References}

A.S.T.M. (2012) American Society for Testing and Materials. Designation, (D1447-07), (D1448-97), (D1445-67).

Abdel-Aal, Amal S.A., Hamoda, S.A.F. and Ibrahim, M.A.A. (2014) Effect of different sources of potassium on growth and productivity of cotton. Egypt. J. Appl. Sci. 29(11), 562-572.

Abou-Zaid, M.K., Emara, M.A. and Hamoda, S.A. (2013) Effect of humex and bio-fertilization on growth, yield and quality of cotton under calcareous soil conditions. The $2^{\text {nd }}$ Alexandria International Cotton Conference, Faculty of Agric., Saba Basha, Alexandria, Univ., Alex. 10-11 April, 2013, Vol. 1, pp. 12-21.

Ali, H., Afzal, M., Ahmad, S. and Muhammad, D. (2009) Effect of cultivars and sowing dates on yield and quality of (Gossypium hirsutum L.). Crop. J. Food Agri. Environ. 7, 244-247.

Arshad, M., Wajid, A., Maqsood, M., Hussain, K. and Aslam, M. (2007) Response of growth, yield and quality of different cotton cultivars to sowing dates. Pak. J. Agric. 44(2), 208-212.

Bange, M., Caton, S. and Milroy, S. (2008) Managing yields of high fruit retention in transgenic cotton (Gossypium hirsutum L.) using sowing date. Australian J. Agric. Res. 59(8), 733-741.

Basbag, S. (2008) Effects of humic acid application on yield and quality of cotton. Asian J. of Chemistry, 20(3), 1961-1966.

Chapman, H.D. and Parker, F.P. (1981) "Methods of Analysis of Soil, Plants and Water". Univ. California, August, 1981. Second Printing.

Deshish, El-D., Hamoda, S.A.F. and Emara, M.A.A. (2015) Study of new irrigation systems under planting dates to increasing productivity of cotton. Egypt J. Appl. Sci. 30(12), 564-573.

Elhamamsey, M.H., Ali, E.A. and Emara, M.A.A. (2016) Effect of some cultural practices on shedding and yield of Egyptian cotton. Assiut J. Agric. Sci. 47(4), 41-51.

Emara, M.A. (2012) Response of cotton growth and productivity to application of potassium and zinc under normal and late sowing dates. J. Plant Production, Mansoura Univ. 3(3), 509-514.

Emara, M.A. (2014) Effect of some sources of potassium fertilizers on cotton production under calcareous soil conditions. Egypt. J. Appl. Sci. 29 (11), 597-622.

Emara, M.A., Abdel-Aal, Amal S.A. and Hamoda, S.A. (2015 a) Effect of water stress and foliar feeding with boron and zinc under NPK fertilizer levels on growth and yield of the new promising cotton genotype (Giza 86 x 10229). Fayoum J. Agric. Res. Dev. 30(1), 27-48.

Emara, M.A., Abdel-Aal, Amal S.A. and Hamoda, S.A. $(2015 \mathrm{~b})$ Effect of times and methods of potassium fertilizer on yield and yield components of new hybrid cotton (Giza $86 \times 10229)$ under early and late sowing. Fayoum J. Agric. Res. Dev. 30(1), 17-26.

Emara, M.A.A., Abdel-Aal, Amal S.A. and El-Gabiery, A.E. (2016) Effect of sowing dates and bio-fertilizer under different NPK fertile levels on growth, yield and fiber of promising hybrid cotton Giza (86 X 10229). Egypt. J. Appl. Sci. 31(12), 357-376.

Emara, M.A.A. and Abdel-Aal, Amal S. (2017) Effect of nano-fertilizer on productivity of cotton under nutrient stress conditions. Egypt. J. Appl. Sci. 32(12B), 445-458.

Gomaa, M.A., Radwan, F.I., Ibrahim, I.A., Emara, M.A. and Kattosh, A.A. (2014) Response of Egyptian cotton to soil and foliar potassium application under calcareous soil conditions. J. Adv. Agric. Res., Fac. Agric. (Saba Basha), 19(2), 236-246.

Hamoda, S.A.F., Ibrahim, M.A. and Emara, M.A.A. (2014) Effect of irrigation intervals and NPK fertilizers on growth, yield and quality for new hybrid cotton [Giza 83 (Giza 75 x 5844)] x Giza 80. The $1^{\text {st }}$ International Cotton Conference "Challenges to Sustainable Cotton Production \& Guality”. Egypt. J. Agric. Res. (Special Issue), 92(1), 111-123.

Hearn, A.B. (1981) Cotton nutrition. Field Crop Abst. 34(1), 11-34.

Morteza, M., Slaton, A., Evans, E., McConnell, J., Fred, M. and Kennedy, C. (2005) Effect of potassium fertilization on cotton yield and petiole potassium. Summaries of Arkansas Cotton Res. pp. 74-78. 
Policepatil, A., Chittapur, B. and Paramesh, V. (2009) Response of Bt cotton hybrids for targeted yield under Northern transitional zone of Karnataka. Journal of Crop and Weed, 5(1), 313-315.

Seadh, S.E., El-Hendi, M.H. and El-Sayed, Shiamaa O.S. (2012) Effect of NPK rates and humic acid on growth of Egyptian cotton. J. Plant Pro., Mansoura, 3(8), 2287-2299.

Snedecor, G.W. and Cochran, W.G. (1980) "Statistical Methods". $7^{\text {th }}$ ed, pp. 225-269. Iowa State Univ., U.S.A.
Uchida, R. (2000) Essential nutrients for plant growth: Nutrient functions and deficiency symptoms. In: "Plant Nutrient Management in Hawaiis Soils. Approaches for Tropical and Subtropical Agriculture". Chapter 3, pp. 31-55.

Temz, M., Karahan, E. and Koca, Y. (2009) Effects of humic substances on cotton. Asian Journal of Chemistry, 21(3), 1983-1989.

أجريت تجربة حقلية بمحطة البحوث الزر اعية بالجميزة، محافظة الغربية في أرض طينية خلال موسمي 2016،

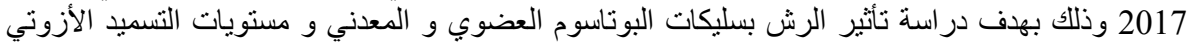

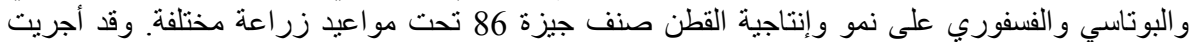

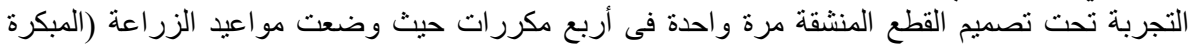

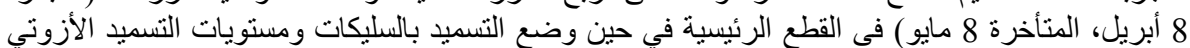

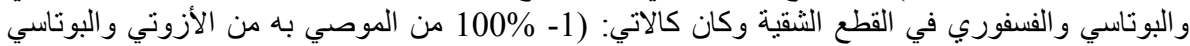

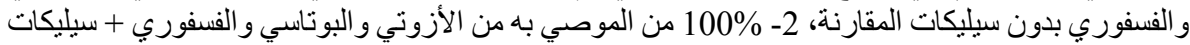

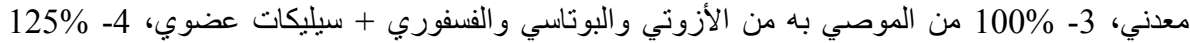

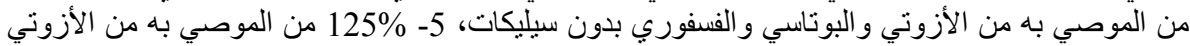

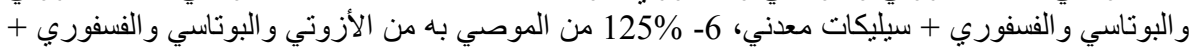

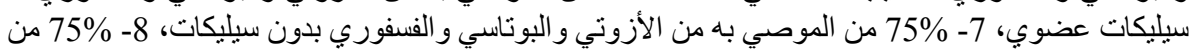

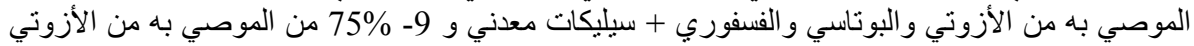

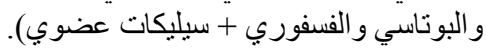
وتتلخص أهم النتائج المتحصل عليها فيما يلى:

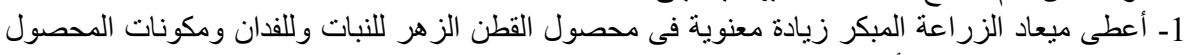

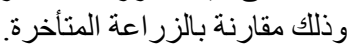

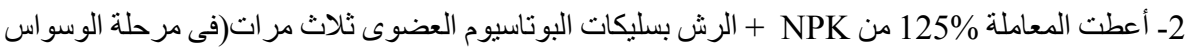

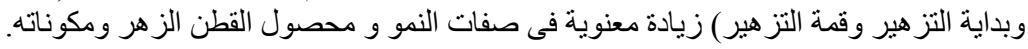

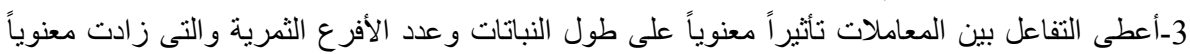

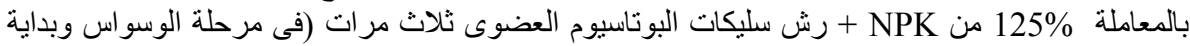
التز هير وقمة التز هير ) وذذلك في ميعاد الزر اعة المتأخر. 4- لم يكن هناك أية تأثثر ات معنوية لمعاملات الدارسة وفئ والتفاعل بينها على جميع صفات الزعة التيلة.

عموماً ومن النتائج المتحصل عليها في هذه الدر اسة فأنه يمكن التوصية بالزر اعة المبكرة مع التسميد بالمعدل

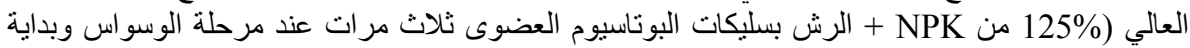

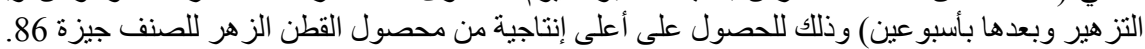

